\title{
The origin of low-MgO eclogite xenoliths from Obnazhennaya kimberlite, Siberian Craton
}

\author{
J. SUN ${ }^{1 *}$, R.L.RUDNICK ${ }^{2}$, S.I. KOSTROVITSKY ${ }^{3}$,

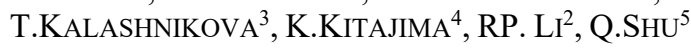 \\ ${ }^{1}$ College of Geosciences, China University of Petroleum, \\ Beijing, China; *sunjingvv@163.com. \\ ${ }^{2}$ Department of Earth Science and Earth Research Institute, \\ University of California, Santa Barbara, CA, USA. \\ ${ }^{3}$ Institute of Geochemistry, Siberian Branch of Russian \\ Academy of Sciences, Irkutsk, Russia. \\ ${ }^{4}$ Department of Geoscience, University of Wisconsin- \\ Madison, WI, USA. \\ ${ }^{5}$ State Key Laboratory of Ore Deposit Geochemistry, Institute \\ of Geochemistry, Chinese Academy of Sciences, Guiyang, \\ China.
}

The petrology, mineral major and trace element concentrations, and garnet oxygen isotopic composition of low-MgO (11-16 wt.\%) eclogites from the Obnazhennaya kimberlite, Siberian craton, are used to infer their petrogenesis. These eclogites equilibrated at moderate pressure-temperature conditions $2.3-3.7 \mathrm{GPa}$ and 855 $1095^{\circ} \mathrm{C}$ at the time of entrainment. Although derived from the garnet stability field, these rocks have low-pressure cumulate protoliths containing plagioclase, olivine, and clinopyroxene as reflected by pronounced positive $\mathrm{Eu}$ and $\mathrm{Sr}$ anomalies in all eclogites, and low heavy rare earth element (HREE) contents in both minerals and reconstructed bulk rocks for a number of samples. Major elements, transition metals, and the HREE compositions of the reconstructed whole rocks are analogous to modern oceanic gabbro cumulates. Despite geochemical signatures supporting an oceanic crust origin, mantle-like $\delta^{18} \mathrm{O}$ of the garnets $(5.07-5.62 \% 0)$ for most samples indicates that the protoliths either did not interact with seawater or have coincidently approximately normal igneous values. Some of the eclogite xenoliths have lower $\mathrm{SiO}_{2}$ contents and depleted light $\operatorname{REE}\left((\mathrm{Nd} / \mathrm{Yb})_{\mathrm{N}}<1\right)$ compared to modern oceanic gabbros, suggesting that they experienced partial melting. Positively inclined middle to heavy-REE patterns $\left((\mathrm{Dy} / \mathrm{Yb})_{\mathrm{N}}<1\right)$ of the reconstructed bulk rocks mostly result from repeated partial melting in the eclogite stability field, based on melting model calculations. We therefore suggest that the Obnazhennaya low-MgO eclogites may represent the gabbroic section of subducted or foundered basaltic crust that underwent continued partial melting processes at high pressures where garnet was the main residual phase. 